\title{
Perbandingan Penerapan Metode Inquiry Terbimbing Dan Metode Inquiry Bebas Termodifikasi Terhadap Kemampuan Pemecahan Masalah Matematika Siswa
}

\author{
Muhammad Zulfikar ${ }^{1)}$, Thamrin Tayeb ${ }^{2)}$, Mardhiah ${ }^{3)}$ \\ ${ }^{1,2,3}$ Fakultas Tarbiyah dan Keguruan UIN Alauddin Makassar \\ $\underline{\text { muhammadzul27fikar@gmail.com }}{ }^{l)}, \underline{\text { thamrinthayeb@yahoo.com }}{ }^{2)}, \underline{\left.\text { mardhiah.diah@uin-alauddin.ac.id }{ }^{3}\right)}$
}

\begin{abstract}
Abstrak
Tujuan penelitian ini yaitu untuk mengetahui perbandingan penerapan metode inquiry terbimbing dan inquiry bebas termodifikasi terhadap kemampuan pemecahan masalah siswa kelas VIII SMPN 21 Kota Makassar. Jenis penelitian yang digunakan yaitu quasi experimental dengan desain non equivalent control group design. Populasi dalam penelitian ini adalah seluruh Siswa Kelas VIII SMP Negeri 21 Kota Makassar tahun ajaran 2017-2018. Teknik sampling yang digunakan pada penelitian ini adalah teknik sampling acak sederhana (purposive sampling). Sampel dalam penelitian ini

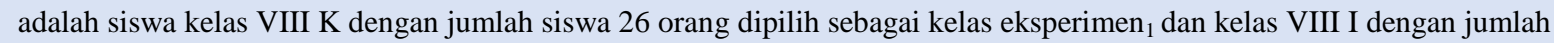
27 orang dipilih sebagai kelas eksperimen ${ }_{2}$. Teknik analisis data yang digunakan adalah statistik deskriptif dan statistik inferensial. Berdasarkan hasil analisis deskriptif menunjukkan bahwa rata-rata kemampuan pemecahan masalah matematika siswa dengan metode inquiry terbimbing adalah 84,73 berada pada kategori sangat tinggi sedangkan metode inquiry bebas termodifikasi berada pada kategori tinggi serta nilai rata-rata 76,83. Berdasarkan hasil penelitian dapat disimpulkan bahwa metode inquiry terbimbing lebih efektif meningkatkan kemampuan pemecahan masalah matematika dibandingkan metode inquiry bebas termodifikasi siswa kelas VIII SMPN 21 Kota Makassar.
\end{abstract}

Kata Kunci: Pemecahan Masalah Matematika, Metode Inquiry Terbimbing, Metode Inquiry Bebas Termodifikasi

\section{Pendahuluan}

Pendidikan suatu proses dalam rangka mempengaruhi siswa agar dapat menyesuaikan diri sebaik mungkin terhadap lingkungannya dan dengan demikian akan menimbulkan perubahan dalam dirinya yang memungkinkannya untuk berfungsi secara kuat dalam kehidupan masyarakat. Pengajaran bertugas mengarahkan proses ini agar sasaran dari perubahan itu dapat tercapai sebagaimana yang diinginkan. Tujuan pendidikan mengarahkan dan membimbing kegiatan guru dan siswa dalam proses pengajaran. Karena ada tujuan yang jelas maka semua usaha dan pemikiran guru ditinjau ke arah pencapaian tujuan itu. Sebaliknya apabila tidak ada tujuan yang jelas maka kegiatan pengajaran tidak mungkin berjalan sebagaimana yang diharapkan dan tidak akan memberikan hasil yang diinginkan (Hamalik, 2004).

Manusia yang hanya menguasai pelajaran belum tentu dapat mengembangkan kemampuan berpikir secara optimal, namun sebaliknya siswa akan dapat mengembangkan kemampuan berpikirnya manakala ia bisa menguasai materi pelajaran (Sanjaya, 2009). Mata pelajaran matematika perlu diberikan kepada semua peserta didik mulai dari sekolah dasar sampai menengah untuk membekali mereka dengan kemampuan berpikir logis, analitis, sistematis, kritis, kreatif, cermat, efektif dan efisien serta kemampuan bekerja sama dalam pemecahan masalah. Matematika merupakan salah satu cabang ilmu pengetahuan yang mempunyai peranan penting dalam perkembangan ilmu pengetahuan dan teknologi, baik sebagai alat bantu dalam penerapan-penerapan bidang ilmu lain maupun dalam pengembangan matematika itu sendiri (Hamzah \& Muhlisraini, 2014). Hasil pembelajaran yang merupakan salah satu indikator mutu pendidikan lebih banyak ditentukan. Mutu pendidikan pada hakikatnya adalah bagaimana proses pembelajaran yang dilakukan guru di kelas berlangsung secara bermutu dan bermakna. Selain guru dan siswa, subsistem yang juga sangat penting dalam peningkatan mutu pendidikan adalah kurikulum yang diterapkan. Salah satu upaya untuk 
meningkatkan kualitas pendidikan adalah dengan mengadakan perbaikan dalam proses pembelajaran (Praptiwi, 2012).

Tujuan mata pelajaran matematika untuk semua jenjang pendidikan dasar dan menengah adalah agar siswa mampu: (1) memahami konsep matematika, menjelaskan keterkaitan antar konsep, dan mengaplikasikan konsep atau algoritma secara luas, akurat, efisien, dan tepat dalam pemecahan masalah; (2) menggunakan penalaran pada pola dan sifat, melakukan manipulasi matematika dalam membuat generalisasi, menyusun bukti, atau menjelaskan gagasan dan pernyataan matematika; (3) memecahkan masalah yang meliputi kemampuan memahami masalah, merancang model matematika, menyelesaikan model, dan menafsirkan solusi yang diperoleh; (4) mengomunikasikan gagasan dengan simbol, tabel, diagram, atau media lain untuk memperjelas keadaan atau masalah; dan (5) memiliki sikap menghargai kegunaan matematika dalam kehidupan, yaitu rasa ingin tahu, perhatian, dan minat dalam mempelajari matematika, serta sikap ulet dan percaya diri dalam pemecahan masalah (Effendi, 2012). Kemampuan pemecahan masalah menjadi salah satu aspek penting yang harus dikuasai siswa dalam pembelajaran matematika. Pemecahan masalah merupakan suatu proses penerimaan tantangan dan kerja keras untuk menyelesaikan masalah tersebut khususnya pemecahan masalah matematis. Berdasarkan lima tujuan yang telah dikemukakan, kemampuan pemecahan masalah memegang peranan penting, karena selain sebagai tuntutan pembelajaran matematika, kemampuan tersebut juga bermanfaat bagi siswa dalam kehidupan sehari-hari. Hal ini didukung oleh fakta bahwa poin utama penilaian pada studi internasional seperti Thrends International Mathematics Science Study (TIMSS) dan Programme for International Student Assessment (PISA) adalah kemampuan pemecahan masalah matematika siswa.

Mengefektifkan pembelajaran khususnya matematika diperlukan berbagai metode pembelajaran untuk meningkatkan kemampuan pemecahan masalah matematika siswa. Sama halnya dengan beberapa sekolah tingkat menengah yang ada di Indonesia, salah satu sekolah yang menjadi fokus pengamatan bagi peneliti adalah SMPN 21 Kota Makassar. Berdasarkan hasil wawancara dengan guru matematika di sekolah tersebut menyatakan bahwa metode pembelajaran yang diterapkan di sekolah sebagian besar masih menggunakan pembelajaran konvensional ataupun pembelajaran yang berpusat pada guru. Sehingga peserta didik tidak diberikan kebebasan untuk memecahkan sendiri masalah pembelajaran yang dihadapinya. Dalam memecahkan masalah seperti soal cerita, siswa merasa bingung terkait maksud dari soal. Kebiasaan siswa $45 \%$ dalam menjawab langsung pada penyelesaiannya atau tidak menentukan apa yang diketahui soal dan syarat dari soal. Kemampuan pemecahan masalah matematika siswa kelas VIII SMPN 21 Kota Makassar masih ketegori rendah dan siswa belum bisa menuliskan kesimpulan dari soal. Siswa lebih cenderung menyelesaikan soal tanpa menuliskan langkah-langkah penyelesaian dengan lengkap, sehingga siswa tidak memahami maksud dan isi dari soal. Dari data wawancara dengan guru matematika SMPN 21 Kota Makassar pada mata pelajaran matematika terdapat $40 \%$ siswa yang nilainya masih dibawah Kriteria Ketuntasan Minimal (KKM) yang ditetapkan sekolah yaitu 77.

Berdasarkan hasil survei yang dilakukan oleh TIMSS tahun 2015, Indonesia berada pada urutan ke- 45 dari 50 negara dengan skor rata-rata 397 (Infographic, 2015). Sedangkan survei PISA pada tahun 2015, menyatakan bahwa prestasi matematika siswa Indonesia berada pada peringkat 63 dari 72 negara dengan skor rata-rata 386 (Kebudayaan, 2017). Berdasarkan data survei tersebut dapat disimpulkan bahwa kondisi pembelajaran matematika belum memenuhi harapan salah satunya disebabkan oleh kemampuan pemecahan masalah matematis siswa yang masih rendah. 
Memilih metode pembelajaran yang menarik dan dapat memicu siswa untuk ikut serta aktif dalam kegiatan belajar mengajar sangat diperlukan. Selain pembelajaran kooperatif dengan berbagai tipe ada beberapa metode pembelajaran yang membuat peserta didik ikut serta aktif dalam proses pembelajaran diantaranya adalah metode pembelajaran inquiry. Hubungan terhadap inquiry yang disebut inquiry yang berpusat pada masalah (problem-centered inquiry) (Hamalik, 2009). Sehingga metode pembelajaran inquiry merupakan salah satu metode yang dapat mendorong siswa untuk belajar aktif dalam pembelajaran. Metode inquiry adalah cara penyajian pelajaran yang memberi kesempatan kepada peserta didik untuk menemukan informasi dengan atau tanpa bantuan guru. Metode inquiry melibatkan peserta didik proses-proses mental dalam rangka penemuan memungkinkan para peserta didik menemukan sendiri informasi-informasi yang diperlukan untuk mencapai tujuan belajar. Dari pendapat Wina Sanjaya (2009) mengenai metode inquiry, memberikan tekanan bahwa metode inquiry itu adalah kegiatan pembelajaran yang melibatkan seluruh kemampuan siswa untuk mencari dan menyelidiki sesuatu masalah secara kritis, logis, dan analitis sehingga siswa dapat menemukan jawaban atau pemecahan dari suatu masalah. Metode inquiry terbagi atas metode inquiry terbimbing dan metode inquiry bebas termodifikasi. Pembelajaran inquiry terbimbing yaitu metode pembelajaran inquiry yang dalam pelaksanaannya guru menyediakan bimbingan atau petunjuk cukup luas kepada peserta didik. Metode pembelajaran inquiry bebas termodifikasi memiliki ciri guru hanya memberikan permasalahan tersebut melalui pengamatan, percobaan, atau prosedur penelitian untuk memperoleh jawaban (Baki, 2012). Inquiry terbimbing merupakan kegiatan inquiry dimana masalah dikemukakan oleh guru atau bersumber dari buku teks kemudian siswa bekerja untuk menemukan jawaban terhadap masalah tersebut di bawah bimbingan yang intensif dari guru. Inquiry tipe ini, tergolong kategori inquiry terbimbing karena siswa dibimbing secara hati-hati untuk menemukan jawaban terhadap masalah yang dihadapkan. Pembelajaran inquiry terbimbing bermanfaat memberi bantuan mengembangkan kemampuan dalam memahami pengetahuan baru yang dipelajari (Budiati, 2016).

Metode pembelajaran inquiry bebas termodifikasi merupakan kegiatan inquiry yang mengharuskan siswa untuk merencanakan proses penelitian atau membuat langkah-langkah dalam menyelesaikan masalah sedangkan guru hanya menyiapkan masalah dan menyediakan bahan-bahan yang diperlukan oleh siswa. Selanjutnya, siswa diberikan kebebasan yang cukup luas untuk memecahkan masalah. Guru mengajukan pertanyaan-pertanyaan yang dapat membantu siswa mengerti arah pemecahan masalah, bukan menjelaskan apa yang akan dilakukan. Satu aspek penting yang membedakan adalah pemberian kebebasan kepada siswa untuk merumuskan dan mengatasi permasalahan yang diberikan, baik secara individu maupun kelompok.

Berdasarkan berbagai uraian di atas, maka perlu diadakan penelitian untuk membandingkan penerapan kedua metode pembelajaran tersebut. Dalam hal ini penulis bermaksud meneliti tentang "Perbandingan Penerapan Metode Inquiry Terbimbing dan Metode Inquiry Bebas Termodifikasi terhadap Kemampuan Pemecahan Masalah Matematika Siswa Kelas VIII SMPN 21 Kota Makassar".

\section{Metode Penelitian}

Penelitian ini menggunakan penelitian dengan pendekatan kuantitatif dengan jenis penelitian eksperimen semu (quasi eksperimental). Desain penelitian yang digunakan adalah non equivalent control group design. Desain ini terdapat dua kelompok eksperimen yang diberi perlakuan. Kelompok eksperimen $n_{1}$ adalah kelompok yang diajar menggunakan metode inquiry terbimbing dan kelompok eksperimen $_{2}$ adalah metode inquiry bebas termodifikasi. Kelas eksperimen $n_{1}$ dan eksperimen $_{2}$ diberi pretest, kemudian diberikan perlakuan, dan terakhir diberikan posttest. Populasi dalam penelitian ini 
adalah seluruh siswa kelas VIII SMP Negeri 21 Kota Makassar tahun ajaran 2017-2018. Teknik sampling yang digunakan pada penelitian ini adalah teknik purposive sampling. Sampel dalam penelitian ini adalah siswa kelas VIII K dengan jumlah siswa 26 orang dipilih sebagai kelas eksperimen $_{1}$ dan kelas VIII I dengan jumlah 27 orang dipilih sebagai kelas eksperimen .

Penulis menggunakan teknik pengumpulan data untuk memperoleh data yang dibutuhkan. Sesuai dengan instrumen penelitian yang digunakan, pengumpulan data pada penelitian ini dilakukan dengan teknik tes tertulis. Pada penelitian ini, dilakukan dua kali tes untuk setiap kelas, yaitu pretest dan posttest. Instrumen yang digunakan pada penelitian ini berupa instrumen tes yang berupa soal essay. Data hasil penelitian diolah menggunakan statistik deskriptif dan statistik inferensial. Analisis statistik deskriptif digunakan untuk mengetahui gambaran secara umum kemampuan pemecahan masalah matematika siswa. Analisis statistik inferensial digunakan untuk menguji hipotesis penelitian dengan menggunakan uji independent sample t-test kemudian dilanjutkan dengan uji efisiensi relative. Namun sebelumnya dilakukan terlebih dahulu uji normalitas dan uji homogenitas sebagai uji prasyarat.

\section{Hasil}

Tabel berikut adalah hasil analisis deskriptif data kemampuan pemecahan masalah matematika siswa dengan menggunakan metode inquiry terbimbing di kelas VIII K (kelas eksperimen $\left._{1}\right)$

Tabel 1. Statistik Deskriptif Kemampuan Pemecahan Masalah Matematika Kelas Eksperimen

\begin{tabular}{lcc}
\hline \multirow{2}{*}{ Statistik } & \multicolumn{2}{c}{ Nilai Statistik } \\
\cline { 2 - 3 } & Pretest & Posttest \\
\hline Nilai Terendah & 21 & 71 \\
Nilai Tertinggi & 50 & 100 \\
Rata-Rata $(\overline{\boldsymbol{x}})$ & 32,42 & 84,73 \\
Standar Deviasi (SD) & 8,04 & 7,34 \\
\hline
\end{tabular}

Jika kemampuan pemecahan masalah matematika siswa dikelompokkan dalam kategori sangat rendah, rendah, sedang, tinggi, dan sangat tinggi akan diperoleh frekuensi dan persentase setelah dilakukan pretest dan posttest sebagai berikut.

Tabel 2. Kategori Kemampuan Pemecahan Masalah Matematika Kelas Eksperimen ${ }_{1}$

\begin{tabular}{|c|c|c|c|c|c|}
\hline \multirow{2}{*}{$\begin{array}{c}\text { Tingkat } \\
\text { Penguasaan }\end{array}$} & \multirow{2}{*}{ Kategori } & \multicolumn{2}{|c|}{ Pretest Kelas Eksperimen $_{1}$} & \multicolumn{2}{|c|}{ Posttest Kelas Eksperimen $_{1}$} \\
\hline & & Frekuensi & Persentase (\%) & Frekuensi & Persentase (\%) \\
\hline $0-20$ & Sangat Rendah & 0 & 0 & 0 & 0 \\
\hline $21-40$ & Rendah & 21 & 80,76 & 0 & 0 \\
\hline $41-60$ & Sedang & 5 & 19,23 & 0 & 0 \\
\hline $61-80$ & Tinggi & 0 & 0 & 8 & 30,76 \\
\hline $81-100$ & Sangat Tinggi & 0 & 0 & 18 & 69,23 \\
\hline \multicolumn{2}{|c|}{ Jumlah } & 26 & 100 & 26 & 100 \\
\hline
\end{tabular}

Berdasarkan tabel di atas, dapat disimpulkan bahwa persentase terbesar kemampuan pemecahan masalah matematika siswa kelas eksperimen ${ }_{1}$ pada saat pretest berada pada kategori 
rendah dan persentase terbesar kemampuan komunikasi matematis siswa kelas eksperimen ${ }_{1}$ pada saat posttest berada pada kategori tinggi.

Berikut ini adalah tabel hasil analisis deskriptif data kemampuan pemecahan masalah matematika siswa dengan menggunakan metode inquiry bebas termodifikasi di kelas VIII I (kelas eksperimen $_{2}$ ).

Tabel 3. Statistik Deskriptif Kemampuan Pemecahan Masalah Matematika Kelas Eksperimen ${ }_{2}$

\begin{tabular}{lcc}
\hline \multirow{2}{*}{ Statistik } & \multicolumn{2}{c}{ Nilai Statistik } \\
\cline { 2 - 3 } & Pretest & Posttest \\
\hline Nilai Terendah & 16 & 65 \\
Nilai Tertinggi & 52 & 100 \\
Rata-Rata $(\bar{x})$ & 28,5 & 76,83 \\
Standar Deviasi (SD) & 9,84 & 8,14 \\
\hline
\end{tabular}

Jika kemampuan komunikasi matematis siswa dikelompokkan dalam kategori sangat rendah, rendah, sedang, tinggi, dan sangat tinggi akan diperoleh frekuensi dan persentase setelah dilakukan pretest dan posttest sebagai berikut:

Tabel 4. Kategori Kemampuan Komunikasi Matematis Kelas Eksperimen ${ }_{2}$

\begin{tabular}{clcccc}
\hline \multirow{2}{*}{$\begin{array}{c}\text { Tingkat } \\
\text { Penguasaan }\end{array}$} & \multirow{2}{*}{ Kategori } & \multicolumn{2}{c}{ Pretest Kelas Eksperimen } & Posttest Kelas Eksperimen $_{\mathbf{2}}$ \\
\cline { 3 - 6 } & & Frekuensi & Persentase (\%) & Frekuensi & Persentase (\%) $^{(\%)}$ \\
\hline $0-20$ & Sangat Rendah & 3 & 11,11 & 0 & 0 \\
$21-40$ & Rendah & 21 & 77,77 & 0 & 0 \\
$41-60$ & Sedang & 3 & 11,11 & 0 & 0 \\
$61-80$ & Tinggi & 0 & 0 & 22 & 81,48 \\
$81-100$ & Sangat Tinggi & 0 & 0 & 5 & 18,51 \\
& Jumlah & 27 & 100 & 27 & 100 \\
\hline
\end{tabular}

\section{Pembahasan}

Berdasarkan persentase dari hasil pretest dan posttest disimpulkan bahwa persentase terbesar kemampuan pemecahan masalah matematika siswa kelas eksperimen ${ }_{2}$. Pada saat pretest berada pada kategori rendah hal tersebut dikarenakan dan persentase terbesar kemampuan komunikasi matematis siswa kelas eksperimen ${ }_{2}$ pada saat posttest berada pada kategori tinggi. Sebelum menerapkan metode inquiry terbimbing, kategori kemampuan pemecahan masalah matematika siswa 80,76\% berada pada kategori rendah, hal tersebut terjadi karena sebagian besar siswa masih mengalami kesulitan dalam menuliskan informasi dan permasalahan yang terdapat pada suatu soal, kesulitan mengidentifikasi unsur-unsur yang diketahui dalam soal, kesulitan merumuskan masalah atau menyusun model matematika, serta masih terdapat beberapa siswa yang hanya menghitung angka-angkanya tanpa mengetahui maksud dari soal ataupun tanpa mengetahui arti dari setiap langkah-langkah penyelesaian soal tersebut.

Setelah menerapkan metode inquiry terbimbing, kategori kemampuan pemecahan masalah matematika siswa $69,23 \%$ berada pada kategori tinggi, hal tersebut terjadi karena dengan menggunakan metode inquiry terbimbing siswa dapat menemukan dan mengembangkan keterampilan berfikir dan mendapatkan jawaban atas dasar rasa ingin tahu mereka dan petunjuk dari guru serta 
dengan berdiskusi siswa juga mampu menggunakan istilah dan notasi matematika untuk memodelkan suatu permasalahan matematika, serta dapat menarik kesimpulan sendiri dari apa yang telah diperoleh. Selain itu dengan banyaknya kesempatan berdiskusi, siswa juga menjadi mengetahui maksud dari permasalahan yang ada, tidak hanya menghitung angka-angkanya tetapi juga mengetahui arti dari setiap langkah-langkah penyelesaian soal tersebut. Berdasarkan uraian di atas dapat disimpulkan bahwa metode inquiry terbimbing mampu meningkatkan kemampuan pemecahan masalah matematika siswa.

Sebelum menerapkan metode inquiry bebas termodifikasi, kategori kemampuan pemecahan masalah matematika siswa $77,77 \%$ berada pada kategori rendah, hal tersebut terjadi karena sebagian besar siswa masih mengalami kesulitan dalam menuliskan informasi dan permasalahan yang terdapat pada suatu soal, kesulitan mengidentifikasi unsur-unsur yang diketahui dalam soal, kesulitan merumuskan masalah atau menyusun model matematika, serta masih terdapat beberapa siswa yang hanya menghitung angka-angkanya tanpa mengetahui maksud dari soal ataupun tanpa mengetahui arti dari setiap langkah-langkah penyelesaian soal tersebut. Sedangkan, setelah menerapkan metode inquiry bebas termodifikasi, kategori kemampuan pemecahan masalah matematika siswa 81,48\% berada pada kategori tinggi, hal tersebut terjadi karena dengan menggunakan metode inquiry bebas termodifikasi siswa dapat menemukan dan mengembangkan keterampilan berpikir dan mendapatkan jawaban atas dasar rasa ingin tahu mereka secara mandiri atau tanpa bimbingan dan petunjuk dari guru, memecahkan masalah, mencari sendiri model matematika dari permasalahan yang ada dan saling membantu memahami pekerjaan mereka masing-masing, sehingga siswa mampu menuliskan informasi dan masalah yang diperoleh, dengan berdiskusi siswa juga mampu menggunakan istilah dan notasi matematika untuk memodelkan suatu permasalahan matematika pada soal sehingga siswa tidak hanya sekadar menghitung angka-angkanya tetapi juga mengetahui arti dari setiap langkah-langkah penyelesaian soal tersebut. Berdasarkan uraian di atas dapat disimpulkan bahwa metode inquiry bebas termodifikasi mampu meningkatkan kemampuan pemecahan masalah matematika siswa.

Berdasarkan pengamatan dan hasil analisis peneliti bahwa terdapat perbedaan antara penerapan metode inquiry terbimbing dan metode inquiry bebas termodifikasi, hal ini dikarenakan adanya kelebihan dan kekurangan dari setiap metode pembelajaran tersebut. Kondisi dari dua kelas yang diambil sebagai sampel memiliki sedikit perbedaan, dimana tingkat konsentrasi kelas $\mathrm{K}$ lebih baik dari kelas I. Sehingga terdapat perbedaan rata - rata kemampuan awal siswa yang tidak terlalu jauh. Tetapi data yang diperoleh berdistribusi normal dan homogen. Cahyani (2016) dalam penelitiannya mengemukakan bahwa terdapat perbedaan rata-rata pembelajaran matematika dengan metode inqury terbimbing dari pada metode inquiry bebas termodifikasi terhadap kemampuan awal siswa. Efektif tidaknya suatu metode pembelajaran tidak ditentukan oleh kecanggihan metode tersebut, namun seperti pada prinsipnya tidak ada satu metode pembelajaran yang terbaik. Metode pembelajaran yang terbaik adalah metode pembelajaran yang sesuai dengan tujuan pembelajaran yang hendak dicapai. Dalam penelitian ini setiap kelas diberikan materi yang sama namun dengan metode pembelajaran yang berbeda. Meskipun terdapat perbedaan, tetapi dalam pembelajaran matematika dengan menggunakan metode inquiry terbimbing dan metode inquiry bebas termodifikasi diyakini dapat membuat siswa lebih aktif dan memberikan kesempatan kepada siswa untuk menemukan sendiri dalam mengungkapkan ide atau gagasan matematis dengan cara argumentasi dalam diskusi internal kelompok maupun antar kelompok serta pada pembelajaran ini, peran guru sebagai fasilitator sementara siswa berpikir, dan melatih siswa menghargai pendapat orang lain. Berdasarkan hasil penelitian, peneliti dapat melihat bahwa metode inquiry terbimbing lebih efektif meningkatkan 
kemampuan pemecahan masalah matematika siswa dibandingkan dengan metode inquiry bebas termodifikasi pada siswa kelas VIII SMP Negeri 21 Kota Makassar.

Hasil penelitian tersebut terjadi disebabkan perbedaan keadaan dalam kelas, perbedaan kemampuan pemecahan masalah matematika siswa yang terjadi dapat disebabkan juga oleh beberapa faktor, seperti kemampuan peneliti untuk menguasai kelas tidaklah sama, kelas dengan metode inquiry terbimbing memiliki semangat yang tinggi untuk mengikuti proses pembelajaran sehingga lebih mudah untuk diarahkan, sementara di kelas yang menggunakan metode inquiry bebas termodifikasi siswa memliki semangat yang kurang baik sehingga lebih sulit untuk diarahkan seperti saat pembelajaran berlangsung di kelas VIII K dari 26 siswa ada 13 siswa yang bertanya dan di kelas VIII I hanya ada 5 siswa. Selain itu, perbedaan sintaks metode pembelajaran juga dapat berpengaruh terhadap hasil pembelajaran, seperti pada kelas VIII $\mathrm{K}$ dengan metode inquiry terbimbing siswa berdiskusi secara langsung di dalam kelompok sedangkan pada kelas VIII I dengan metode inquiry bebas termodifikasi terlebih dahulu siswa diarahkan untuk berpikir secara mandiri sedangkan siswa di kelas tersebut sulit diarahkan untuk berpikir secara mandiri.

Walaupun demikian, dari penelitian yang telah dilakukan dengan menerapkan metode inquiry terbimbing dan metode inquiry bebas termodifikasi, keduanya dapat meningkatkan kemampuan pemecahan masalah matematika siswa kelas VIII SMPN 21 Kota Makassar.

\section{Kesimpulan}

Penerapan metode inquiry terbimbing dan inquiry bebas termodifikasi dapat meningkatkan kemampuan pemecahan masalah matematika siswa kelas VIII SMP Negeri 21 Kota Makassar. Terdapat perbedaan yang signifikan antara kelas yang menggunakan metode inquiry terbimbing dan kelas yang menggunakan metode inquiry bebas termodifikasi terhadap kemampuan pemecahan masalah matematika siswa kelas VIII SMP Negeri 21 Kota Makassar. Penerapan metode inquiry terbimbing lebih efektif meningkatkan kemampuan pemecahan masalah matematika siswa dibandingkan dengan metode inquiry bebas termodifikasi.

\section{Daftar Pustaka}

Baki, A. N. (2012). Metode Pembelajaran Agama Islam. Makassar: Alauddin University Press.

Budiati, H. (2016). Scientific Approach based Guided inquiry with Smart Messages to Improve Observation Skill and Learning Outcome. Bioedukasi, 2(9), 35.

Cahyani, Eko Diah. "Pembelajaran Matematika Berbasis Masalah dengan Strategi Inquiry Terbimbing dan Inquiry Bebas Termodifikasi Ditinjau dari Kemampuan Awal Siswa MTs", Jurnal Pendidikan, Vol 28, No. 2 (2016). Journals.ums.ac.id (Diakses 16 Mei 2017).

Effendi, L. A. (2012). Pembelajaran Matematika dengan Metode Penemuan Terbimbing untuk Meningkatkan Kemampuan Representasi dan Pemecahan Masalah Matematika Siswa SMP. Jurnal Penelitian Pendidikan, 13(2). Retrieved from Eprints.ums.ac.id

Hamzah, M. A., \& Muhlisraini. (2014). Perencanaan dan Strategi Pembelajaran Matematika. Jakarta: raja Grafindo Persada.

Hamalik, Oemar. Proses Belajar Mengajar. Jakarta : Bumi Aksara, 2004.

Infographic, T. (2015). Situs Resmi Analytical and Capacity Development Partnership (ACDP). Retrieved from https:www.acdp-indonesia.org

Kebudayaan, K. P. dan. (2017). Peringkat dan Capaian PISA Indonesia Mengalami Peningkatan. Retrieved from Official Website Kementerian Pendidikan dan Kebudayaan website: https://www.kemdikbud.go.id 
Praptiwi, L., Sarwi, \& L. Handayani," Efektivitas Model Pembelajaran Eksperimen Inkuiri Terbimbing Berbantuan My Own Dictionary Untuk Meningkatkan Penguasaan Konsep Dan Unjuk Kerja Siswa SMP RSBi”, Unnes Science Education Journal, Vol 1 No 2 (2012). h.1 http://journal.unnes.ac.id/sju/index.php/usej. (Diakses 10 Mei 2017).

Sanjaya, Wina. Strategi Pembelajaran Berorientasi Standar Proses Pendidkan. Jakarta : Kencana, 2009. 